\title{
Designing a Flood Storage Option on Agricultural Land: What Can Flood Risk Managers Learn from Drought Management?
}

\author{
Rosalind H. Bark (D)
}

Citation: Bark, R.H. Designing a

Flood Storage Option on Agricultural Land: What Can Flood Risk

Managers Learn from Drought

Management? Water 2021, 13, 2604.

https://doi.org/10.3390/w13182604

Academic Editor: Pavol Miklánek

Received: 11 August 2021

Accepted: 17 September 2021

Published: 21 September 2021

Publisher's Note: MDPI stays neutral with regard to jurisdictional claims in published maps and institutional affiliations.

Copyright: (C) 2021 by the author. Licensee MDPI, Basel, Switzerland. This article is an open access article distributed under the terms and conditions of the Creative Commons Attribution (CC BY) license (https:// creativecommons.org/licenses/by/ $4.0 /)$.
School of Environmental Sciences, University of East Anglia, Norwich NR4 7TJ, UK; r.bark@uea.ac.uk

\begin{abstract}
The increasing probability of loss and damage to floods is a global concern. Countries are united by an urgent need to reduce flood risk to households, businesses, agricultural land, and infrastructure. As natural and engineered protection erodes with climate change and development pressures, new approaches to flood risk management delivered at the catchment scale that work with nature hold promise. One nature-based solution that aligns with this Special Issue on river flooding is the temporary storage of floodwaters on the floodplain. In many countries, this would involve controlled flooding inland low-lying agricultural land. Designing schemes that farmers and irrigation districts will adopt is essential. To inform future floodplain storage options, we review farm-centred drought management, specifically, agreements that transfer agricultural water to municipalities through fallowing in California, USA and an Australian farm exit scheme. These initiatives reveal underpinning principles around the need to: balance the multiple objectives of the parties, share the benefits and responsibilities, address local impacts and practical guidance on incentive design including the consideration of conditional participation requirements and responding to farmer and public preferences. In terms of funding there is opportunity for blended financing with flood-prone communities, insurers, and conservation charities.
\end{abstract}

Keywords: nature-based solutions; floodplain storage; payments for farmers; drought and flood management

\section{Introduction}

Climate change is eroding built flood defences around the world, and in combination with other pressures, the flood regulation services delivered by natural ecosystems [1,2]. The outcome is more households, businesses, infrastructure, and farmland are at risk from flooding [1-4]. To reduce the probability of severe impacts, there is an urgent need for better flood risk management [1,2]. As disaster relief, recovery costs, and a rise in shared trauma, governments are primed to explore new approaches to flood risk preparedness and reduction $[1,5]$, including multi-functional landscape management, restoring degraded land, urban green infrastructure, and insurance [6-10]. Strengthening flood risk management tools and investing in flood risk reduction meets two of the four UN Sendai Framework for Disaster Risk Reduction priorities (Priority 2 and 3, UN, 2015). Under Priority 3, the expectation is that disaster reduction will be achieved 'through structural and non-structural measures' [11]. In this paper, our focus is on flood risk management related to fluvial flooding.

For individuals, perceptions of risk of flood-related trauma and damage [12] and action often diverge [13]. Enhancing resilience may require the broadening of community boundaries to be inclusive of other actors and other communities [14]. This broadening might drive a post-flood discourse that would otherwise get stuck in adaptation and neglect flood risk reduction [15]. Flood events through their shared trauma can result in the emergence of "extreme weather publics" [16] of affected households, insurance companies, businesses, and governments. Such new publics are critical because flood disaster relief provided to affected households, businesses, and to local governments 
for clean-up/rehabilitation [17] can lead to the externalisation of responsibility, diluting incentives for those at risk to engage in preparedness and flood reduction investment. There is a risk that government response to low-frequency but high-impact disasters will lead to post-disaster investment that is maladaptive to climate change [18]. That is, disaster relief that is not followed up by flood reduction action could disrupt the transition into a risk society [19].

Flood insurance compensates those affected by flooding. Insurance works when risks are pooled and take up is high to counter adverse selection and moral hazard. Yet, in high-income countries, the uptake of flood insurance is low [20] and largely non-responsive to different products [21]. Meanwhile, access to flood insurance is poor in developing countries, and households and businesses here may have preferences for an uninsured status quo because of institutional trust issues [22]. To counter issues of access and affordability, governments subsidise premiums or can operate reinsurance schemes. The UK's reinsurance scheme, Flood Re, is available to flood-prone households, and in the USA, the Federal Emergency Management Agency underwrites the National Flood Insurance Program (NFIP). (See https:/ / www.floodre.co.uk/ and https:/ / www.fema.gov/flood-insurance accessed on 2 September 2021.) These programmes ensure that households can access affordable private flood insurance products. However, flood insurance typically just compensates flood victims but does not increase household or business flood resilience, unless insurers require that flood-affected properties are rebuilt with property-level flood risk adaptation (PLFRA) measures [23].

Indeed, when Scottish households were given a choice between a natural flood management (NFM) option and a locally funded flood insurance option, they preferred the NFM option [24]. The authors found household choice was motivated by a desire for prevention and not just for compensation. This preference to reduce or avoid flooding is rational given large estimates of household willingness to pay to reduce the impact of flooding, inclusive of the intangible and psychological effects associated with flooding [23]. An option that combines insurance and reduces flood risk could be attractive, not only to households in flood-prone areas, but also to businesses, infrastructure managers, and farmers.

The USA's NFIP has a Community Rating System (CRS) which marries flood risk reduction efforts (the CRS) with the government-underwritten flood insurance scheme (the NFIP). The CRS provides incentives for at-risk communities to invest in non-/structural flood protection and damage reduction activities to receive $5 \%$ to $45 \%$ discounts on NFIP premiums [25]. Researchers have found that the CRS generates incentives for purchases of flood insurance [26-28]; preparedness and mitigation, particularly in densely populated and wealthier communities [28]; and results in lower insurance claims from participating communities [1]. However, as designed, it neither generates incentives for communities to adopt more complex flood reduction investments $[7,29]$ nor to incorporate ex situ flood reduction activities. This is particularly pertinent as risk reduction investment, in some instances, might not be effective within a community, but rather would be best provided ex situ, for example, a community might benefit from an upstream unmodified river catchment or from temporary floodplain floodwater storage. Furthermore, an option that extends this next generation of flood (re)insurance schemes to the wider catchment would fit with contemporary flood risk management paradigms that work at the whole catchment scale, or 'wholescape' [30].

For inland river flooding, in those areas where rivers remain unmodified, floodplain conservation is a priority. Kousky and Walls (2014) [31] estimate the value of floodplain conservation using the case study of the Meramec Greenway project in Missouri, USA. First, using a GIS-based flood model and a counterfactual developed floodplain scenario, they estimate avoided flood damage costs to be USD 7.7 million a year. Second, using a hedonic property analysis, they consider the co-benefits of floodplain conservation, estimating that recreation and aesthetic values are capitalized in nearby properties at USD 22.9 million a year. These estimated benefits exceed estimates of the annual opportunity 
cost of preservation. Crucially, the authors find that flood damage is heterogenous across the floodplain, and therefore, they recommend fine targeting of parcels for protection, and potentially for floodplain floodwater storage options, to lower the cost of floodplain conservation and potential storage. This contrasts with the generic national Weighted Annual Average Damage (WAAD) estimates of annual average avoided flood losses ([32], Section A1.24) that are used for flood reduction scoping analyses in the UK.

In situations where river catchments are modified, ex situ flood regulation could be delivered by farmers through a suite of NFM interventions on-land, for example, retention basins on fields, the controlled flooding of fields, meadows and forests, the creation of wetlands, afforestation, and reduced tillage (see, [33]). Specifically, here, we are interested in a larger-scale NFM intervention, lowland inland floodplain floodwater storage [34] and not schemes primarily focused on the uplands [35]. An advantage of temporary floodplain floodwater storage as compared to designating the floodplain as conservation land, is that during flood events agricultural land would be flooded in a controlled and compensated manner, but at all other times, farmers could continue to farm their land as usual. Such an arrangement is akin to the Californian agricultural fallowing agreements, whereby agricultural land is temporarily fallowed but otherwise remains in production.

The UK government already invests in NFM measures, and in 2020, renewed its pledge to continue to invest in NFM measures [35,36]. Following exit from the European Union, new agricultural payment schemes based on the principle of "public money for public goods" may boost NFM funding [36,37]. The centrepiece of reform is the Environmental Land Management scheme (ELMs), which will operate at three geographical scales, with Tier 2 payments for 'locally targeted' activities, including NFM on-land [38]. With the full roll out set for 2024, 'test and trial' pilots [38] and other research can inform ELMs. One of 60 test and trials is investigating the use of reverse auctions for NFM offers in Somerset, southwestern UK. A reverse auction is where a seller of an environmental good (e.g., a farmer) submits a bid to the buyer (e.g., the UK government), noting what they will offer and the price they are willing to sell at (e.g., $X$ hectares of woodland planting at GBP X per hectare). Reverse auctions are designed to promote competition between potential providers of environmental goods, thereby reducing programme costs. Reverse auctions have been successful in engaging UK farmers in water quality improvements, specifically with farmers bidding to implement interventions to reduce nitrate runoff. (See, https: / / www.catchments.ie/ using-reverse-auctions-to-support-delivery-of-catchm ent-off-sets-in-wessex-uk / accessed on 2 September 2021) and the state of Victoria, Australia, has significant experience with reverse auctions (called 'conservation tenders') [39].

A key difference with reverse auctions, where a set of competing farmers deliver water quality or biodiversity, is that delivering floodplain floodwater storage requires cooperation across farm boundaries. It might be that novel types of reverse auctions are more appropriate for the targeted landscape-scale provision of ecosystem services. For example, researchers have experimented with new reverse auction formats, such as follow-up formats, where a second round auction follows if the target is not met in the first round [40]; or through payment of agglomeration bonuses [33,41] or agglomeration payments paid only if all targeted landowners participate [33]; and provision point reverse auctions (PPRAs), where the probability that a contract will be accepted is based on a provision point requirement [42].

Other funding options could include payments for ecosystem services (PES) or voluntary agreements. Flood regulation is an example of a 'regional directional' regulating ecosystem service, where the benefits of, for example, floodplain floodwater storage, are provided to downstream or adjacent residential areas [43]. Flood regulation is also a type of one-to-many PES scheme with one buyer (e.g., local government) and multiple landowners provisioning the ecosystem service [44]. There is potential for a PES or other negotiated agreement whereby the beneficiary, for instance, a new type of authority, such as the Somerset Rivers Authority [45], or a town or city, pays farmers for changes to their land and water management practices $[33,46]$. As floodplain floodwater storage options are 
novel and farmers are cautious to adopt NFM interventions [47], particularly larger-scale interventions [33], salient lessons on incentive design might be forthcoming from elsewhere, for example, from farm-centred drought management.

In this paper, we review voluntary dry-year (fallowing) options that transfer water from irrigated agriculture to municipalities in California, USA, and a voluntary farm exit package in the Murray-Darling Basin, Australia and propose that they offer useful design principles and practical contract elements that could inform future flood storage agreements in the UK (and elsewhere). The paper ends with a set of next steps around floodplain storage opportunity mapping and the consideration of farmers' and public preferences in floodplain storage option design.

\section{Learning from Drought Management}

Using documents, including reports and legal contracts, we review two Californian (fallowed) water transfer agreements and the Murray-Darling Basin water efficiency programme with the aim to inform the design of a future UK-based floodplain floodwater storage scheme. First, background on the drought management schemes is provided, and then, we propose a set of principles and incentive design elements that underpin these schemes.

\subsection{Background to Farmer-Centred Drought Programmes}

The fallowing agreements and financial package described below are examples of spatially targeted programmes designed to reallocate water between specified parties.

\subsubsection{Fallowing Agreements}

The two Californian water transfer schemes transfer(ed) 'conserved' Colorado River water-water entitlements that were not sold-from irrigation districts to regional water wholesalers. The large volumes of water involved in these transfers required the irrigation district to agree to the contracted arrangements. The specific long-term fallowing contracts are between the San Diego County Water Authority and the Imperial Irrigation District (SDCWA-IID) and the Metropolitan Water District of Southern California and the Palo Verde Irrigation District (MWDSC-PVID). The direction of the water transfers reflects both the relative size of, and the priority of, water entitlements held to Colorado River water, where the MWDSC and SDCWA have smaller and more junior water entitlements ([48], [49] (Table 4-1), [50]).

SDCWA-IID: The SDCWA serves 24 member agencies that deliver water to 3.3 million residents in San Diego County [51] and the IID covers around 470,000 acres (190,202 hectares) in the Imperial Valley and has an annual entitlement of 3.1 million acre feet (AF) (3823.8 GL) [52]. In 1988, the IID and SDCWA signed a 45-year agreement for the Implementation of a Water Conservation Program and Use of Conserved Water (to end December 2041); the approval agreement was signed in 1989 and can be extended by mutual agreement for a further 30 years. This agreement provides the SDCWA with a long-term option of the transfer of up to 300,000 AF (370 gigalitres, GL) of IID irrigated water made available through fallowing or on-farm and system-wide conservation [53]. As part of a wider Colorado River settlement, in 2003, the IID and SDCWA amended the 1988 agreement, and a further amendment was signed in 2007.

Two key aspects of the 2003 agreement are around ramping up transferred volumes and the utilisation of fallowing. In 2003, just 20,000 AF of conserved (24.7 GL,) water was transferred through fallowing, with the agreed transfer volumes rising to a maximum 200,000 AF (246.7 GL) by 2021. In 2021, the maximum 200,000 AF (246.7 GL) was set to be transferred to the SDCWA [54]. This is all conserved water not only water transferred from fallowing. This reliance on fallowing for transferred volumes was time limited; in the first 15 years of the agreement only, water transferred was made available through conservation measures and agricultural land fallowing in the Imperial Valley. Annual programmes ran from July to June, i.e., fallowing a winter crop and a summer crop. Transfer volumes from 
fallowing reached over 100,000 AF (123.3 GL) in the 2012-2013, 2013-2014, 2014-2015, and 2016-2017 fallowing programmes [55]. From 2017, the land fallowing component of the agreement reduced to zero. (See figure IID/SDCWA Water Conservation Schedule Fallowing at https:/ / www.iid.com/water/water-conservation/fallowing accessed on 2 September 2021). In 2010, to facilitate this switch from fallowing to on-farm and irrigation district level conservation the SDCWA provided USD 50 million to the IID.

MWDSC-PVID: The MWDSC is a regional wholesaler that supplies water to 26 member public agencies that deliver water to 19 million residents of southern California. (See http:/ / www.mwdh2o.com/WhoWeAre/Mission/Pages/default.aspx accessed on 2 September 2021). The PVID covers around 91,400 acres (36,988 hectares) in the Palo Verde Valley [56] and its annual water entitlement is specified as what is needed to irrigate its land. On August 16, 2004, the MWDSC-PVID signed a 35-year Forebearance and Fallowing Program Agreement ("programme agreement") [57]. Legally, each participating landowner (or tenant with landowner approval) signs a "landowner agreement" with the MWDSC and the PVID. A Fallowing Easement Deed encumbers the participating landowner's qualifying land for the benefit of the PVID and MWDSC. The MWDSC must manage fallowing so that an average of 12,000 acres (4856 hectares) is fallowed each year over the contract period. In terms of water volumes, the programme transfers up to $116,580 \mathrm{AF}(143.8 \mathrm{GL})$ annually. In the period 2005-2017, 1.3 million AF (1603.5 GL) of conserved water was transferred from agriculture to urban southern California at a cost of USD 162.7 million [56].

\subsubsection{MDB Exit Package}

The Australian Commonwealth (federal) Government has instituted various policies to reallocate water from irrigators to the environment in the Murray-Darling Basin, southeastern Australia. Water purchasing "buyback" options were central [58]. Here, we are specifically interested in targeted buybacks aimed to facilitate the exit of groups of smallholder irrigators in "unviable or inefficient sections of irrigation schemes" ([58], page 4), closing irrigation spurs, and thereby improving the overall efficiency of the irrigation infrastructure. In 2008, the federal government announced a AUD 57.1 million Small Block Irrigators Exit Grant Package. The scheme opened in South Australia in late 2008 and elsewhere in the Basin in early 2009. It targeted small-scale irrigators, particularly horticulturalists, offering them a package of funding to sell their entitlements to the Commonwealth government $[59,60]$. (See, https:/ / www.agriculture.gov.au/water/mdb/programs/basin-wide accessed on 2 September 2021).

\subsection{Key Design Elements to Take Forward to Floodplain Floodwater Storage Agreements}

From the document analysis of the drought management schemes we suggest that there are five key elements to consider when designing agreements with farmers.

\subsubsection{Balancing Objectives}

The overall goals of the programmes are not simply to transfer water or facilitate farmer exit from farming but rather combine several different aims. For instance, the MWDSC-PVID water transfer is described as "an urban-agricultural partnership", where "preserving farming identity is a key priority of (the) partnership" ([56] page 2). The two high-level aims identified might appear to compete; however, it is in the design of the transfers that these dual goals are reconciled. It is also a recognition that there are advantages to water transfer agreements to the contractee, such as water price stability, and that they have benefits over alternative policies; for instance, outright water entitlement purchase is fraught with risk of political resistance [61]. For the MDB Exit package, the goals were to reallocate water whilst offering participating farmers an opportunity to pay down debt [62] and to maintain community. 


\subsubsection{Managing the Agreement}

Subscription conditions: The MWDSC-PVID programme agreement was conditional on landowners subscribing a minimum 13,250 acres (5362 hectares) as participating acreage. To put this minimum participation into context, full subscription acreage is 26,500 acres $(10,724$ hectares). Meanwhile, the SDCWA-IID fallowing agreement has a process for dealing with over-subscription; if, following a Solicitation Announcement, more offers to fallow were received than those required to meet the IID's fallowing commitment, the IID would undertake a random selection process. Those landowners/tenants missing out would be given priority in the next fallowing programme [63].

Solicitation: In both fallowing agreements, it is the contracee that undertakes programme management. The PVID manages the fallowing programme, soliciting participation from landowners of Priority 1 Land receiving Priority 1 Water and maintaining a database of records, notifying the MWDSC of any violations, etc [48]. Fallowing easements are conveyed to the PVID and MWDSC [64]. Similarly, under the SDCWA-IID fallowing programme, the contract was between participating landowners/tenants and the IID.

Rules for repeat enrolment: Both fallowing agreements have processes to share the benefits of the agreement between landowners. In the MWDSC-PVID agreement, there are several rules around fallowing intensity that are covered in Exhibit A of the landowner agreement [64], such as: the: (1) landowner's maximum fallowing commitment; (2) landowner's base fallowing amount-25\% of their maximum fallowing commitment; and (3) the landowner's minimum average fallowing acreage- $-45.3 \%$ of maximum fallowing commitment for all 35 contract years. The PVID has the job of allocating fallowing proportionately among enrolled landowners in accordance with the 10-year maximum fallowing commitment they offer [65]. At any time, enrolment in the fallowing agreement can reach 26,500 acres (29\% of PVID land). As land under fallowing is rotated every one to five years, all enrolled farmers can participate in fallowing [56]. Such rotation may improve soil health and reduce negative externalities from fallowing, such as dust $[61,66]$.

The SDCWA-IID fallowing agreement allows landowners/tenants to participate in fallowing contracts for up to two consecutive years, after which the land is not eligible for two subsequent years [63].

Monitoring and enforcement: The IID has a right of entry onto a participating landowner/ tenant's farm to verify compliance with the fallowing contract [63]. Similarly, for the MWDSC-PVID agreement, participating irrigators have to agree that with $24 \mathrm{~h}$ notice, the MWDSC has a right to enter and inspect fallowed land [64]. Furthermore, the US Bureau of Reclamation verifies the PVID fallowing programme as per the programme agreement [48], calculating Programme Saved Water as well as inspecting around 5\% of enrolled fallowed land using a combination of PVID water delivery records, visual inspection, and photographs of fallowed fields [67].

Scope for an emergency programme: In 2003-2004, the SDCWA-IID had an emergency fallowing programme based on bids [68]. In 2009, the MWDSC and PVID entered a one-year emergency fallowing programme to benefit drought-affected California. Landowners with Priority 1 Water were solicited on 24 March 2009 to enrol up to $15 \%$ of their land not already fallowed under the MWDSC-PVID 35-Year fallowing programme. Under this "Emergency Short-Term Fallowing Program", a further 13,222 acres (5351 hectares) was fallowed, 'conserving' 24,078 AF (29.7 GL) of water.

\subsubsection{Eligibility Criteria}

Targeting: The MWDSC-PVID fallowing programme is only open to landowners irrigating Priority Land with Priority 1 water entitlements [56]. The MDB Exit package was open to irrigators with a minimum 10 megalitres in tradeable water entitlements [60].

History of farming: Participation in the MWDSC-PVID fallowing programme is conditional on the land having a history of farming determined, by whether the land was irrigated in two of the five years over the period of 1999-2003 [64]. Eligibility for participation in the SDCWA-IID annual fallowing programmes was open to landowners/tenants 
with eligible fields that had been farmed (irrigated for crops) in the previous 3 years and with a history of water use so that a baseline water use history could be calculated (the average water use applied in the period 1987-1995, capped at 6 AF per acre) [63].

Minimum field/farm size: Participation in the MWDSC-PVID fallowing programme is conditional on land parcels being compact and of at least 5 acres [64]. Eligibility for participation in the SDCWA-IID annual fallowing programmes was open to landowners/tenants that met the following eligibility criteria, namely with eligible fields: at least 10 acres in size and completely within the IID. Under the initial MDB Exit package scheme qualified irrigators with holdings of less than 15 hectares were eligible; the scheme was expanded in February 2009 to smallholders with between 15 and 40 hectares [60].

Infrastructure requirements: Eligibility for IID irrigators requires that water delivery gates can be locked for a single field, or if multiple fields are served by one water gate, that all participate in the programme [63]. Infrastructure reconfiguration was also key in the MDB package.

History of compliance: A condition of the SDCWA-IID fallowing agreement was that no field would be eligible for annual fallowing programmes if it was delinquent in water delivery or water availability charges and irrigators had to demonstrate compliance with other programmes [63]. Similarly, for the MWDSC-PVID agreement, participating irrigators had to pay off all water tolls, standby, and other charges owed [69].

\subsubsection{Payment Design}

Up-front payment: All participating PVID landowners were paid an initial payment or hosting payment for each enrolled acre in their maximum fallowing obligation at USD 3171 per water toll acre. The landowner could choose one of four payment options, whereby $2 / 3 / 4 / 5$ separate instalments were made over $2 / 3 / 4 / 5$ years, respectively [48]. There is no up-front payment in the IID agreement, perhaps reflecting the relative size of the district and its water entitlements as compared to PVID. Eligible smallholders to the MDB Exit package could receive up to AUD 150,000, plus AUD 10,000 towards advice and retraining, and up to AUD 20,000 in other transition payments in return for offering their water entitlements for sale to the Commonwealth tendering process [60].

Exercise payment: The MWDSC-PVID landowner agreement [64] includes an annual payment schedule for fallowed acres in Exhibit C, whereby in the first contract year of 2006, annual payments were USD 602 per fallowed acre (USD 1487/ha), with payments rising by $2.5 \%$ each year up until the tenth year and then by the Consumer Price Index subject to a $2.5 \%$ minimum and $5 \%$ maximum per year thereafter (e.g., $+2.5 \%$ each year, USD 1394/fallowed acre (USD 3445/ha) in 2039). For the MWDSC-PVID emergency fallowing programme in 2009-2010, landowners had to start fallowing between 15 April and 1 August 2009. Payments offered for this short-term, short notice programme were higher than under the long-term agreement (to take account of lost crops), with MWDSC offering USD 1665 for each water toll acre and USD 35 per acre paid to the PVID [70].

For the initial year of the SDCWA-IID fallowing agreement, landowners submitted a bid for the emergency fallowing programme. Thereafter, the IID offered a set price per AF. This offer was USD 60/AF in the 2004-2005 to 2006-2007 fallowing programmes, rising to USD 175/AF in the 2014-2015 to 2016-2017 farm unit fallowing programme. (See https:/ / www.iid.com/water/water-conservation/fallowing accessed on 2 September 2021). Contract payments for fallowing were paid in three equal payments, with the final payment conditional on having met contract provisions [63]. Furthermore, there is transparency in the payments made to each landowner, for instance, in the period 2004-2017, the IID made USD 160.75 million in fallowing payments to over 730 named recipients [71].

A condition of irrigators receiving the MDB Exit package was that they could not re-enter irrigation for five years [59].

Option trigger: Using data on storage, demand, and supply forecasts, the MWDSC determines its need to make a 'fallowing call' on enrolled irrigators in the PVID [59]. 
A fallowing call must be received by the August preceding the next growing year and once triggered, is active for a period of at least 2 years. There are several fallowing obligations that are described in the programme agreement [57]. There is a minimum annual fallowing obligation of $7 \%$ of the full subscription acreage (approximately 6000 acres) to be fallowed in each year of the 35-year agreement. There are also limits on the fallowing; under full subscription, up to 24,000 acres can be fallowed for a maximum of 25 contract years [48] and the full 26,500 acres can only be fallowed in a maximum of 10 contract years. Providing the MWDSC with more flexibility, it owns around 22,000 acres in the PVID that are also part of fallowing programme.

\subsubsection{Externality Management}

Environmental: Land enrolled in the MWDSC-PVID fallowing agreement is rotated every one to five years based on soil and water management plans [56]. Exhibit F of the landowner agreement [64] notes the environmental management measures that landowners agree as part of the fallowing programme. These include weed, erosion, and dust control. In the SDCWA-IID fallowing agreement, the landowner/tenant is responsible for dust and weed control [63]. As part of the eligibility requirements, specifically if a fallowing programme is over-subscribed, the IID will consider the location of the proposed fields and their effect on environmental mitigation costs [63].

Local-level third party impacts: Fallowing reduces irrigation demand and therefore third-party impacts to the irrigation district. To ensure that the PVID does not lose income from the fallowing programme, MWDSC pays the PVID USD 35 an acre [69] and landowners are liable to pay taxes, levies, and other payments to the PVID for encumbered land, but not for any additional charges for saved water [64]. Furthermore, the MWDSC pays the US Bureau of Reclamation all charges for the delivered water to PVID [72]. Similarly, IID farmers are liable for all water charges, fees, and taxes [63]. If a fallowing programme is over-subscribed, the IID can consider the location of the proposed fields and their effect on IID operations and maintenance costs [63].

Regional-level third party impacts: Fallowing reduces agricultural production, thereby reducing regional demand for agricultural products (e.g., seeds) and services (e.g., agricultural labour). As part of a wider acknowledgement of the third-party impacts to local communities, the MWDSC-PVID agreement includes a USD 6 million Community Improvement Fund [56,73]. This fund is administered by local citizens and has been used to support small business and training [56].

In the 2003 amendment of the SDCWA-IID agreement, a "Local Entity" was set up to offset third party impacts. Non-competitive funds were allocated to the farm service providers and a completive component was managed by the Local Entity [74]. The funding available each year was determined by the volume and timing of fallowing, with annual payments varying from USD 0.41 million in 2012 to USD 13.62 million in 2016 [75]. Over the years 2007-2020, USD 48.21 million was disbursed [75]. Projects eligible for funding are for: business development $(50 \%)$, workforce development $(50 \%)$, and special projects (25\%) [74]. The maximum grant that could be applied for was for USD 400,000, with a $10 \%$ match requirement (cash or in-kind), with funds to be spent within 3 years. Detailed application, rating, awarding, and reporting process information was provided to potential applicants [74]. Consideration for a grant award under the final disbursement of USD 425,000 from the fund had to be submitted by the end of July 2021 [76].

The MDB Exit package provided irrigators with a financial lifeline to keep their homes and stay on their land in their local community $[59,60]$.

A summary of the key features for each of the programmes reviewed is provided in Table 1. 
Table 1. Key features for incentive design.

\begin{tabular}{llll}
\hline & SDCWA-IID & MWDSC-PVID & MDB Exit \\
\hline Balancing objectives & Explicit & Explicit & Explicit \\
\hline Managing the agreement & & & \\
Subscription conditions & Yes & Yes & N/A \\
Solicitation & Yes & Yes & N/A \\
Rules for repeat participation & Yes & Yes & N/A \\
Monitoring and enforcement & Yes & Yes & N/A \\
Emergency programme & Yes & Yes & \\
\hline Eligibility criteria & & & Yes \\
Targeting & Yes & Yes & $?$ \\
History of farming & Yes & Yes & Yes \\
Minimum field/farm size & Yes & Yes & $?$ \\
Infrastructure requirements & Yes & No & \\
History of compliance & Yes & Yes & Yes \\
\hline Payment structure & & & N/A \\
Up-front payment & No & Yes & N/A \\
Exercise payment & Yes & Yes & \\
Option trigger & No & Yes & No \\
\hline Externality management & & & Yes \\
Environmental & Yes & Yes & \\
Local-level third party impacts & Yes & Yes & Yes \\
Regional-level third party impacts & Yes & & \\
\hline
\end{tabular}

\section{Discussion}

In the learning from drought section, we explored actual examples of bilateral agreements and government incentives implemented to manage drought impacts. Here, we discuss design principles and elements using accepted measures to assess the performance of policy instruments (effectiveness, efficiency, and distributional effects) [77,78], before considering next steps.

\subsection{Incentive Design Principles}

Among the key principles that underpin the fallowing agreements, and the exit package is the balancing of multiple objectives of the different parties to the agreements [79], for example, to: diversify the sources of water (to supply the San Diego region) in order to enhance supply risk management and reliability [50]; preserve agriculture [56]; and keep irrigators in their communities [60]. This emphasis on the distributional effects of the incentives likely enhances the stability of the agreements while trading-off against cost effectiveness and efficiency goals. Multiple objectives for any flood storage option agreement in the UK would need to be balanced, such as reducing community flood risk and preserving the rural economy. This balancing of multiple objectives between the parties is also seen in a second principle around sharing the benefits and responsibilities, for example, between the irrigation district and irrigators and among irrigators, like in the MWDSC-PVID and SDCWA-IID agreements. Likewise, UK farmers would need to be compensated to enter into a floodplain floodwater storage agreement for the benefit of, for example, residential areas, and to share the responsibilities for implementing such an agreement, they might make it conditional to the stricter enforcement of floodplain development.

Another key principle is to address local impacts. In the case of water reallocation between uses, residents of rural communities and farmers are often opposed to water trading and transfers for the perceived social and economic impacts on rural areas, areas that often are already suffering declines in population, services, and opportunity $[80,81]$. Likewise, in the UK, PES-type payments to farmers help support a viable agricultural sector and thereby prevent the environmental and social impacts of agglomeration if 
smallholders fail [82]. So, addressing the local impacts of floodplain storage in the design of any floodplain storage option, such as reduced agricultural production, is key.

\subsection{Incentive Design Elements}

\subsubsection{Contracting Parties}

In any PES-like scheme, it is important to identify the buyer(s) and seller(s). Both fallowing agreements are contracted between the municipal water wholesaler and the irrigation district. Although we noted that there are mechanisms to facilitate more efficient water transfers, such as minimum field size and priority for farmers sharing irrigation infrastructure, the drought management schemes reviewed are otherwise indiscriminate between eligible irrigators, whereas to be effective, floodwater storage would require the participation of all contiguous farmers within the target floodplain storage area. Part of this distinction is a false unit of comparison; the fallowing agreements are between a water wholesaler and an irrigation district and not with individual farmers. In the UK, under the new ELMs, agricultural payments for landscape-scale public goods delivery will likely require cooperation across land managers [38,82]. In England, for example, the contracting party might be Internal Drainage Boards (IDB) [83] or the National Farmers Union (NFU, which represents agricultural and horticultural farmers in England and Wales) and not individual farmers. So, like the California examples, a floodplain storage option might be between, for example, a local government and an IDB.

In cases with potential for private (or blended public and private) financing [82], floodplain floodwater storage agreements might be negotiated between an IDB and floodprone urban areas or bodies representing regions, such as the SRA (see, [45]). Private financing could also come from developers and insurers contributing to fund ex situ flood risk reduction linked to lower Flood Re premiums. An example of a contractual arrangement exists in Denmark. In 2018, the Danish municipality, Holstebro, signed a voluntary agreement with 37 farmers to become so-called 'water managers' [84] agreeing to flood a designated area of 150 hectares [33]. The upfront one-off tax-free compensation was EUR 1340/hectare, which far exceeds the gross margin of EUR 200/hectare for permanent grass out of rotation. The authors suggest the high payment might be a result of novelty [33], but without further details on the scheme, it is unclear what the payment covers. It could be that the payment is an up-front payment like in the MWDSC-PVID agreement for a flood storage option, or that it represents multiple 'exercise' payments.

Conservation charities are other potential funders. An example of a conservation agreement that involves flooding is the Bid4Birds program in California [42]. In fall 2020, The Nature Conservancy (TNC) working with two other conservation groups developed the Bid4Birds program. It targets rice farmers, paying them to extend the flooding period on their land (for 3-8 additional weeks of flooding) to create "pop-up" habitats in the shoulder seasons (spring and fall) for the benefit of waterbirds migrating along the Pacific Flyway. Eligible farmers commit to temporarily flooding their enrolled fields to a maximum of 4 inches of water, and other eligibility requirements are that a minimum of 75 acres is enrolled and post-harvest straw management is undertaken. (See https:// calricewaterbi rds.org/practice-requirements / accessed on 2 September 2021). Contracts are ranked. In 2020 , a total of 2659 acres were enrolled into the program. A second round is running in fall 2021, funded by donations to the California Ricelands Waterbird Foundation. (See https:/ / calricewaterbirds.org/fieldwork/2020-shorebird-habitat-projects / and https:/ / calricewaterbirds.org/bid4birds-overview/ accessed on 2 September 2021). In the UK, potential conservation charity partners in a floodplain storage agreement, might be the Royal Society for the Protection of Birds (RSPB), The Rivers Trust, or the TNC.

\subsubsection{Minimum Conditional Participation Requirements}

As coordinated and targeted action is needed to facilitate a floodplain floodwater storage PES, the fallowing agreements provide actual examples of how to design contracts that harness the "neighbourhood effect" [81] to pressure potential holdouts who might 
otherwise attempt to extract higher payments from the buyer or to undermine the objective of the PES [44]. The MWDSC-PVID agreement was conditional on the enrolment of a minimum acreage requirement and the Bid4Birds program uses a provision point reverse auction (PPRA), where the probability that a contract will be accepted is based on a provision point requirement, for example, all farmers within the floodplain participate [42].

Another scheme that contends with holdouts is Anglian Water's "Slug it Out" trial in the east of England. Payments were designed to incentivise farmers within high conservation priority catchments to substitute their use of metaldehyde (a slug control pesticide) with a more benign alternative, ferric phosphate [41]. Specifically, the trial incorporated individual and collective incentives. Participating farmers received: GBP 2.25/ha as a 'hosting payment'; a 'cost difference' payment of GBP 15/ha to compensate them for the more expensive substitute pesticide; and a collective 'water quality bonus' of GBP 2.25/ha, only if, at the end of the trial year, water quality in the catchment met the regulatory standard.

\subsubsection{Layering or Stacking?}

Long experience with water markets in the USA means the long-term fallowing agreements are not viewed through a PES lens. However, they are a type of one-to-many PES where a single ecosystem service is delivered—drinking water. Issues around bundling or stacking different ecosystem services [44] are moot. Through other research [47] and consultancy, we infer that UK farmers have a clear motivation to produce food, but that in exploring PES, the option to stack ecosystem services is attractive, as it would enable them to receive a discrete payment from a buyer for each ecosystem service delivered, often from the same land. Such a stackable PES may attract potential private and conservation buyers for specific ecosystem services, for example, water companies might buy water quality improvements and insurance companies might buy flood regulation services. In contrast, PES buyers might prefer bundling, whereby they pay for one ecosystem service, for example, flood regulation, and receive other ecosystem services delivered as part of the project as co-benefits. Research into wider stakeholder attitudes about NFM in the UK, note that whilst many stakeholders believe co-benefits from NFM interventions are key to the support for NFM that other stakeholders would prefer NFM delivery to focus solely on flood risk reduction [47]. Critical to these discussions is, are ecosystem services synergistically delivered or traded off? (see [34]) and do decision-support tools exist to enable policymakers to design targeted schemes? (see [82]).

\subsubsection{Option Design and Evaluation}

The structure of any floodplain floodwater storage option is important. In contrast to droughts, where a dry-year option designed to limit the impact of droughts on urban consumers is most likely to be triggered to cover peak summer demand, flooding can occur in any season and with limited notice. In either case, an option trigger needs to be "pre-specified, objective, not influenced by actions of parties to the agreement and observable to the participants so that they have a reasonable expectation of the outcome" ([61], page 10). An example of an objective dry-year option trigger is reservoir levels and objective triggers would need to be developed for flood storage options, which could include antecedent soil moisture levels, reservoir and river levels, and information from short- and medium-range forecasting. Linked to potential floodplain floodwater storage, the NFU has requested improvements to the UK's probabilistic modelling of flooding [46]. The UK's Flood Forecasting Centre is working to improve forecasting, for example, by using ENSO information, as there is some evidence that a strong La Niña event in the North Atlantic would be associated with very wet late winters in the UK [85].

There is also a need to objectively evaluate whether an option contract is contributing to its goals [61]. An evaluation can be either input-based, i.e., verification that set management practices are implemented, or output-based, based on delivery against goals [44]. Bateman and Balmford (2018) [82] recommend that future ELMs payments are input-based 
as there is a risk that outcomes might not eventuate. Alternatively, an outcomes assessment would attempt to establish whether an option agreement contributes to a reduction in flooding. The success of an exercised flood storage option could be the absence of, or reductions in the depth ([32], Section A1.22), extent, and duration of flooding [86]. The frequency of flood outcomes avoided might be challenging to model and to explain to those paying for an option; however, here, the visible component to the option, i.e., flooded fields, is an advantage. Evaluating co-benefits, such as biodiversity provisioned by 'popup' habitats [42] and enhanced conjunctive water management delivering improved crop choice flexibility and drought resilience $[46,87,88]$, might be important to the agreement.

Developing a framework to assess outcomes could be useful. Posthumous et al. (2010) [34] developed a 14-indicator framework to assess multiple ecosystem services and other outcomes such as financial returns and employment provisioned by floodplain floodwater storage. To test the framework, the authors then developed five land management scenarios to compare to the status quo and applied it to the 900 ha Beckingham Marshes in the East Midlands, England. They found that for their set of ecosystem services reviewed, there were synergies, for example, between temporary flood storage and agricultural production, and trade-offs, for example, between longer duration flood storage and biodiversity outcomes. A more comprehensive evaluation would not only assess if an option contributes to its goals but also if it does so at the least-cost compared to alternative flood management options, such as built infrastructure, insurance, disaster relief, flood-proofing homes, businesses, and infrastructure, NFM in the uplands, and urban green infrastructure floodwater detention.

\subsubsection{A Role for Intermediaries}

Intermediaries might be essential to reduce transaction costs and to improve the design, implementation, and effectiveness of one-to-many PES schemes [44]. The ELMs test and trials bring attention to the potential influence of intermediaries, for example the Farming Wildlife Advisory Group (FWAG) and large agricultural consultants, such as Brown \& Co [38]; other intermediaries could be conservation charities such as the TNC [42] and RSPB. Intermediaries can solicit advice useful to all farmers, thereby pooling the costs of, for example, tax accountants. This was carried out in the MWDSC-PVID agreement, where the PVID commissioned lawyers to review the tax implications of upfront payments [72]. Furthermore, there is evidence that the exchange of information and experience might improve the social acceptability of farmers participating in novel schemes [45] and that this effect is enhanced if farmers source their information from neighbours and local sources [81].

A role for the government in facilitating the adoption of new land and water management practices in the agricultural sector could be to increase funding for extension services [81]. Two recent OECD reports on improving the agricultural sector's flood preparedness highlighted the potential role of extension services and networks [89,90]. Furthermore, floodplain floodwater storage is just one scheme that has potential to initiate a larger-scale reconfiguration of zoning and agricultural land, where expertise around land sparing (taking land out of production), sharing (integrating nature in agricultural production) and swapping (switching land with another party) $[33,45]$ and tradable development rights (TDRs), is needed.

\subsection{Next Steps}

The multi-decadal fallowing agreements reveal lessons on how to structure floodplain floodwater storage options and provide examples of agreements and landowner and tenancy contracts. The implementation of the agreements also reveals the importance of transparency; for example, information on fallowing recipients and payments is freely available [70]. The MDB Exit programme also reveals lessons on structuring agricultural reconfiguration and exit packages which might be an outcome in some areas where flooding becomes endemic. Although politicians use the enormity of adapting to climate change as 
an excuse for the lack of preparation [91], these programmes are a reminder that leadership to take unpopular decisions and to enforce them, such as ruling out floodplain development and fostering integrated land and water management and planning across government portfolios, is needed.

\subsubsection{Opportunity Mapping}

A first step in designing any new PES-type scheme is to undertake an 'opportunities assessment', combining a: review of policies, plans, initiatives; beneficiary analysis including identifying potential buyers of defined benefits, such as a local community and the insurance industry; and review of funding streams [44]. Indeed, the UK government has indicated its readiness to evaluate opportunities to: "maximise the temporary and permanent storage of water in places or times when flood risk is highest, and, where possible, capture that water to be used when or where needed" ([36], page 20). Integrating such an assessment with potential reform to the Flood Re programme could generate potential for private or blended financing of ex situ flood risk reduction options.

\subsubsection{Consider Farmer Preferences}

A challenge to farmers signing up to an option to flood their land-either temporarily or permanently [36] - is that floodplain land is typically highly productive and flexible to different farm enterprises. In England, 58\% of Grade 1 land is in the floodplain [46]. Therefore, the opportunity costs of floodplain floodwater storage on agricultural land can be high, with costs rising for longer durations of submergence [86]. Although there are risks to grassland from prolonged flooding, the costs of flood hazard, essentially uncontrolled floods, can be high in terms of risks to livestock, damage to fencing, pollution leaks, and costs related to clearing up and land recovery [46]. The NFU is supportive about the potential to supply controlled floodplain floodwater storage options:

Farming has a key role to play in flood management. Where farmers provide a service in mitigating flood risk to help protect others (for example, by providing land that can be flooded seasonally to reduce the severity or frequency of flooding in urban areas downstream) this must be a coherent, planned element of total catchment management. Farmers must be fairly compensated for delivering this service ([46], page 5).

Nevertheless, farmers' preferences to participate in a temporary (or permanent) floodplain floodwater storage scheme are likely to vary by location, farm type, and the risk averseness of the farmer. For instance, floodplain floodwater storage option payments could reduce farmer income variability, and consequently, such schemes might be particularly attractive to risk-averse farmers [66]. Therefore, there is a need to survey UK farmers to better understand their readiness to adopt floodplain floodwater storage options, and such a survey could explore the principles and incentive design elements revealed in the review of the farm-centred drought management programmes.

There is at least one paper that has surveyed farmers (in Denmark) about their preferences towards eleven natural water retention measures (NWRMs). The NWRM options were grouped into three types: water retention, cropping area measures, and changes to water courses [33]. The least popular option was reduced tillage, followed by the controlled flooding of fields, meadows, and forests in river valleys ( $60 \%$ not interested). Less than $20 \%$ responded positively to controlled flooding, where this was described as one controlled flood every 5 years with unspecified intensity. Next, using a choice experiment with the same Danish farmers, the authors investigated their preferences to participate in floodplain storage for the benefit of downstream urban areas. Farmers were hesitant to enter such contracts, particularly if they had experienced flood damage. A set of contractual arrangements were tested, and farmers preferred an option for collective negotiation with other farmers from their sub-catchment, higher annual payments, and a separate payment to compensate for any lost crops. The estimated willingness to accept contracts for floodwater storage with collective negotiation and crop loss compensation was EUR 230 per hectare for farmers with no prior flood experience of crop losses and EUR 409 per 
hectare with such experience (EUR 368/hectare and EUR 547/hectare, respectively, with no crop compensation). In another context, investigating preferences for flood insurance, researchers found that smallholder farmers in Ghana had strong preferences to reduce flood risk and that their estimated annual willingness to pay for a one-year decease in flood frequency was USD 37 [92]. These studies illustrate that farmers can be willing to explore novel arrangements.

\subsubsection{Consider Public Preferences}

A floodplain floodwater storage programme would change land and water management, and the public might hold views on these changes. Research in Colorado, USA investigated householders' views on water supply and demand management options using best-worst choice experiments [93]. Provided with a portfolio of agricultural transfers (to increase supply), non-price conservation, and price increases options, most of the respondents preferred to avoid agricultural transfers. Three latent classes were modelled with two anti-transfer groups comprising $76.8 \%$ of the sample. However, when respondents were confronted with the impacts of the policy options-base charge increases, percentage price increase on bills, and the percentage gap to be met with an agricultural transfer-the pro-transfer latent class rose slightly from $23.2 \%$ to $27.5 \%$ of the sample. In summary, there was support for higher-cost options that avoided impacts on the agricultural sector, but this support weakened when households were faced with future increased costs. Analogously with floodplain floodwater storage, the public might prefer other options, including built flood defences, but might soften their opposition to involving the agricultural sector when faced with the impacts of various policy options. Furthermore, in the Colorado study, a low water use group remained opposed to fallowing, perhaps in part as they would be least affected by price increases. Similarly, it might be that those at lowest risk of flooding would be particularly opposed to any cost increases associated with floodplain floodwater storage options, such as an increase in regional taxes that fund the SRA [45]. However, indirect impacts and disruption from flooding, such as to road and rail travel and through business closures, combined with an aspiration to balance objectives, might lessen such opposition.

\section{Conclusions}

Drought management policy in the USA and Australia is well developed and there is potential to learn across hazards, specifically for flood risk management. A key feature of drought management action in the USA is multi-decadal negotiated agreements. In addition to being long-term solutions, the negotiated agreements are transparent, flexible, and scalable. The framing of these negotiated water transfer agreements around balancing interests, sharing rewards and responsibilities, explicitly addressing local impacts, and minimising holdout behaviour, is useful to the design of any future floodplain floodwater storage option.

The need to rapidly upscale regional climate change action was made clear to global policy makers in the recently published IPCC report [94]. Yet, many workable solutions are likely to be smaller scale and could be negotiated between contracting parties. Here, the Sendai Framework provides broad guidance to local communities and authorities to adopt a multi-hazard approach and to utilise incentives to reduce risk [11]. At this scale, it is advantageous to learn from actual programmes that reduce hazard risk, specifically those negotiated between parties that supply ecosystem services and those that benefit from this provision. Regional and national governments could foster such local action through linking negotiated incentivised solutions within a wider framework of policy action and financial products, such as a community rating flood insurance scheme. 
Author Contributions: Conceptualisation, R.H.B.; methodology, R.H.B.; software, R.H.B.; validation, R.H.B.; formal analysis, R.H.B.; investigation, R.H.B.; resources, R.H.B.; data curation, R.H.B.; writing—original draft preparation, R.H.B.; writing-review and editing, R.H.B.; project administration, R.H.B.; funding acquisition, R.H.B. All authors have read and agreed to the published version of the manuscript.

Funding: The idea behind this research was funded by the European Union's Horizon 2020 research and innovation programme under the Marie Skłodowska-Curie grant No 659449.

Institutional Review Board Statement: Not applicable.

Informed Consent Statement: Not applicable.

Data Availability Statement: Copies of the fallowing contracts and other reports can be requested from the author.

Acknowledgments: The author thanks four anonymous reviewers for their constructive suggestions and for the assistance provided by Water editors.

Conflicts of Interest: The authors declare no conflict of interest.

\section{References}

1. Kousky, C.; Michel-Kerjan, E. Examining flood insurance claims in the United States: Six key findings. J Risk Insur. 2017, 84, 819-850. [CrossRef]

2. IPCC. Climate Change and Land: An IPCC Special Report on Climate Change, Desertification, Land Degradation, Sustainable Land Management, Food Security, and Greenhouse Gas Fluxes in Terrestrial Ecosystems; Intergovernmental Panel on Climate Change: Geneva, Switzerland, 2019.

3. Tellman, B.; Sullivan, J.A.; Kuhn, C.; Kettner, A.J.; Doyle, C.S.; Brakenridge, G.R.; Erickson, T.A.; Slayback, D.A. Satellite imaging reveals increased proportion of population exposed to floods. Nature 2021, 596, 80-86. [CrossRef]

4. Kundzewicz, Z.W.; Su, B.; Wang, Y.; Wang, G.; Wang, G.; Huang, J.; Jiang, T. Flood risk in a range of spatial perspectives-from global to local scales. Nat. Hazard Earth Sys. 2019, 19, 1319-1328. [CrossRef]

5. Ahmadiani, M.; Ferreira, S.; Landry, C.E. Flood insurance and risk reduction: Market penetration, coverage, and mitigation in coastal North Carolina. South Econ. J. 2019, 85, 1058-1082. [CrossRef]

6. IPBES. Summary for Policymakers of the Regional Assessment Report on Biodiversity and Ecosystem Services for the Americas of the Intergovernmental Science-Policy Platform on Biodiversity and Ecosystem Services; Rice, J., Seixas, C.S., Zaccagnini, M.E., Bedoya Gaitán, M., Valderrama, N., Anderson, C.B., Arroyo, M.T.K., Bustamante, M., Cavender-Bares, J., Diaz-de-Leon, A., et al., Eds.; IPBES Secretariat: Bonn, Germany, 2018; 44p.

7. Lwasa, S.; Mugagga, F.; Wahab, B.; Simon, D.; Connors, J.; Griffith, C. Urban and peri-urban agriculture and forestry: Transcending poverty alleviation to climate change mitigation and adaptation. Urban Clim. 2014, 7, 92-106. [CrossRef]

8. Shade, C.; Kremer, P. Predicting Land Use Changes in Philadelphia Following Green Infrastructure Policies. Land 2019, 8, 28. [CrossRef]

9. Soto-Montes-de-Oca, G.; Bark, R.; González-Arellano, S. Incorporating the insurance value of peri-urban ecosystem services into natural hazard policies and insurance products: Insights from Mexico. Ecol. Econ. 2020, 169, 106510. [CrossRef]

10. Christophers, B. The allusive market: Insurance of flood risk in neoliberal Britain. The allusive market: Insurance of flood risk in neoliberal Britain. Econ. Soc. 2019, 48, 1-29. [CrossRef]

11. UN. Sendai Framework for Disaster Risk Reduction 2015-2030. UNISDR/GE/2015-ICLUX EN5000, 1st ed.; United Nations: New York, NY, USA, 2015.

12. Shultz, J.M.; McLean, A.; Herberman Mash, H.B.; Rosen, A.; Kelly, F.; Solo-Gabriele, H.M.; Youngs, G.A., Jr.; Jensen, J.; Bernal, O.; Neria, Y. Mitigating flood exposure. Disaster Health 2013, 1, 30-44. [CrossRef] [PubMed]

13. Wachinger, G.; Renn, O.; Begg, C.; Kuhlicke, C. The Risk Perception Paradox-Implications for Governance and Communication of Natural Hazards. Risk Anal. 2013, 33, 1049-1065. [CrossRef]

14. Ntontis, E.; Drury, J.; Amlôt, R.; Rubin, G.J.; Williams, R. Emergent social identities in a flood: Implications for community psychosocial resilience. J. Community Appl. Soc. 2018, 28, 3-14. [CrossRef]

15. Shepard, S.; Boudet, H.; Zanocco, C.M.; Cramer, L.A.; Tilt, B. Community climate change beliefs, awareness, and actions in the wake of the September 2013 flooding in Boulder County, Colorado. J. Environ. Stud. Sci. 2018, 8, 312-325. [CrossRef]

16. Smith, A.; Jenkins, K. Climate change and extreme weather in the USA: Discourse analysis and strategies for an emerging 'public'. J. Environ. Stud. Sci. 2013, 3, 259-268. [CrossRef]

17. Davlasheridze, M.; Miao, Q. Does governmental assistance affect private decision to insure? An empirical analysis of flood insurance purchases. Land Econ. 2019, 95, 124-145. [CrossRef]

18. Anderson, S.E.; Bart, R.R.; Kennedy, M.C.; MacDonald, A.J.; Moritz, M.A.; Plantinga, A.J.; Tague, C.L.; Wibbenmeyer, M. The Dangers of Disaster-Driven Responses to Climate Change. Nat. Clim. Change 2018, 8, 648-653. [CrossRef]

19. Beck, U. Risk Society: Towards a New Modernity; Sage: London, UK, 1992. 
20. Lamond, J.; Penning-Rowsell, E. The robustness of flood insurance regimes given changing risk resulting from climate change. Clim. Risk Manag. 2014, 2, 1-10. [CrossRef]

21. Achtnicht, M.; Osberghaus, D. The demand for index-based flood insurance in a high-income country. Ger. Econ. Rev. 2017, 20, 217-242. [CrossRef]

22. Reynaud, A.; Nguyen, M.-H.; Auber, C. Is there a demand for flood insurance in Vietnam? Results from a choice experiment. Environ. Econ. Policy Stud. 2018, 20, 593-617. [CrossRef]

23. Joseph, R.; Proverbs, D.; Lamond, J. Assessing the value of intangible benefits of property level flood risk adaptation (PLFRA) measures. Nat. Hazards 2015, 79, 1275-1297. [CrossRef]

24. Glenck, K.; Fischer, A. Insurance, prevention or just wait and see? Public preferences for water management strategies in the context of climate change. Ecol. Econ. 2010, 69, 2279-2291. [CrossRef]

25. FEMA. Federal Insurance and Mitigation Administration. National Flood Insurance Program: Community Rating System. A Local Official's Guide to Saving Lives, Preventing Property Damage, and Reducing the Cost of Flood Insurance. FEMA B 573/2018; FEMA: Washington, DC, USA, 2018.

26. Zahran, S.; Weiler, S.; Brody, S.D.; Lindell, M.K.; Highfield, W.E. Modeling National Flood Insurance Policy Holding at the County Scale in Florida, 1999-2005. Ecol. Econ. 2009, 68, 2627-2636. [CrossRef]

27. Frimpong, E.; Petrolia, D.R.; Harris, A. Community-Level Flood Mitigation Effects on Household Flood Insurance and Damage Claims; Working Paper No. 17-1; Mississippi State University, Department of Agricultural Economics: Starkville, MS, USA, 2017.

28. Li, J.; Landry, C.E. Flood risk, local hazard mitigation, and the Community Rating System of the National Flood Insurance Program. Land Econ. 2018, 94, 175-198. [CrossRef]

29. Brody, S.D.; Zahran, S.; Highfield, W.E.; Bernhardt, S.P.; Vedlitz, A. Policy Learning for Flood Mitigation: A Longitudinal Assessment of the Community Rating System in Florida. Risk Anal. 2009, 29, 912-929. [CrossRef] [PubMed]

30. Acreman, M.; Maltby, E.; Maltby, A.; Bryson, P.; Bradshaw, N. Wholescape Thinking: Towards Integrating the Management of Catchments, Coast and the Sea through Partnerships-A Guidance Note Natural Capital Initiative, London. 2018. Available online: www.naturalcapitalinitiative.org.uk (accessed on 2 September 2021).

31. Kousky, C.; Walls, M. Floodplain conservation as a flood mitigation strategy: Examining costs and benefits. Ecol. Econ. 2014, 104, 119-128. [CrossRef]

32. Treasury, H.M. The Green Book. Central Government Guidance on Appraisal and Evaluation; The Stationery Office: London, UK, 2020.

33. Zanderson, M.; Oddershede, J.S.; Pedersen, A.B.; Nielsen, H.Ø.; Termansen, M. Nature based solutions for climate adaptationPaying farmers for flood control. Ecol. Econ. 2021, 179, 106705. [CrossRef]

34. Posthumus, H.; Rouquette, J.R.; Morris, J.; Gowing, D.J.G.; Hess, T.M. A framework for the assessment of ecosystem goods and services; a case study on lowland floodplains in England. Ecol. Econ. 2010, 69, 1510-1523. [CrossRef]

35. Caldecott, B.; Hall, S.; Ives, E. A Greener, More Pleasant Land: A New Market-Based Commissioning Scheme for Rural Payments. Bright Blue Campaign: London, UK, 2017.

36. H.M. Government. Flood and Coastal Risk Management: Policy Statement; H.M. Government: London, UK, 2020.

37. H.M. Government. A Green Future: Our 25 Year Plan to Improve the Environment. 2018. Available online: www.gov.uk/gover nment/publications (accessed on 16 September 2021).

38. DEFRA. Environmental Land Management. Policy Discussion Document; Department for Environment Food \& Rural Affairs: London, UK, 2020.

39. Rolfe, J.; Whitten, S.; Windle, J. The Australian experience in using tenders for conservation. Land Use Policy 2017, 63, 611-620. [CrossRef]

40. Elliott, J.; Day, B.; Jones, G.; Binner, A.; Smith, G.; Skirvin, D.; Boatman, N.D.; Tweedie, F. Scoping the Strengths and Weaknesses of Different Auction and PES Mechanisms for Countryside Stewardship; Defra: London, UK, 2015. Available online: http:/ / randd.defra. gov.uk/Default.aspx?Menu=Menu\&Module=More\&Location=None\&Completed=0\&ProjectID=19134 (accessed on 2 September 2021).

41. Mohamad Ibrahim, I.H.; Gilfoyle, L.; Reynolds, R.; Voulvoulis, N. Integrated catchment management for reducing pesticide levels in water: Engaging with stakeholders in East Anglia to tackle metaldehyde. Sci. Total Environ. 2019, 656, 1436-1447. [CrossRef]

42. Otto, S.; Poe, G.; Just, D. Provision point reverse auction: A new auction mechanism with applications for conservation contracts. J. Agric. Resour Econ. 2021, 46, 134-151.

43. Fisher, B.; Turner, R.K.; Morling, P. Defining and classifying ecosystem services for decision making. Ecol. Econ. 2009, 68, 643-653. [CrossRef]

44. Smith, S.; Rowcroft, P.; Everard, M.; Couldrick, L.; Reed, M.; Rogers, H.; Quick, T.; Eves, C.; White, C. Payments for Ecosystem Services: A Best Practice Guide; Defra: London, UK, 2013.

45. Bark, R.H.; Acreman, M.C. Investigating social processes that underpin local flood risk management action. Environ. Sci. Policy 2020, 109, 95-102. [CrossRef]

46. NFU. Integrated Water Management; National Farmers Union: London, UK, 2017.

47. Bark, R.H.; Martin-Ortega, J.; Waylen, K. Stakeholders' views on natural flood management: Implications for the nature-based solutions paradigm shift? Environ. Sci. Policy 2021, 1115, 9-98. [CrossRef]

48. PVID-MWD. PVID-MWD Forbearance and Fallowing Program Agreement. 2004, pp. 31-47. Available online: https://www.iid. com/home/showpublisheddocument/17553/636862744820530000 (accessed on 2 September 2021). 
49. CH2MHILL. IID/SDCWA Water Conservation and Transfer Project EIR/EIS-Scoping Summary Report. 2010. Available online: https://www.usbr.gov/lc/region/g4000/IID_FEIS/Vol_5/Apdx_B.pdf (accessed on 16 September 2021).

50. Kendy, E.; Aylward, B.; Ziemer, L.S.; Richter, B.D.; Colby, B.G.; Grantham, T.E.; Sanchez, L.; Dicharry, W.B.; Powell, E.M.; Martin, S.; et al. Water transactions for streamflow restoration, water supply reliability, and rural economic vitality in the western united states. J. Am. Water Resour. Assoc. 2018, 54, 487-504. [CrossRef]

51. SDCWA. Overview: Water Authority Fact Sheet; San Diego County Water Authority: San Diego, CA, USA, 2020.

52. Federal Register. Federal Register: November 6, 2000, Volume 65, Number 215, Pages 66557-66558; Office of the Federal Register: College Park, MD, USA, 2000.

53. Federal Register. Federal Register: September 27, 1999, Volume 64, Number 186, Pages 52102-52104; Office of the Federal Register: College Park, MD, USA, 1999.

54. SDCWA. Colorado River Water Transfer Agreement; San Diego County Water Authority: San Diego, CA, USA, 2020. Available online: https: / / www.sdcwa.org/wp-content/uploads/2020/11/watertransfer-fs.pdf (accessed on 16 September 2021).

55. IID. Imperial Irrigation District Fallowing Program Status Report; IID: Imperial, CA, USA, 2016.

56. MWDSC. Securing Colorado River Supplies: An Urban-Agricultural Partnership in the Palo Verde Valley. 2018. Available online: http:/ / www.mwdh2o.com/PDF_NewsRoom/6.4.2_Water_Reliability_Palo_Verde.pdf (accessed on 16 September 2021).

57. PVID-MWD. PVID-MWD Forbearance and Fallowing Program Term Sheet for Forbearance and Fallowing Program Agreement. 2004, p. 2. Available online: https:/ / www.mwdh2o.com/media/18478/palo-verde-irrigation-dist-mwd-forbearanceandfallow ingprogramagreement.pdf (accessed on 16 September 2021).

58. Page, S.; Goesch, T.; Dyack, B.; Hone, S.; Hughes, N. Purchasing Water in the Murray Darling Basin; ABARE Report to the Department of Environment and Water Resources; Department of Environment and Water Resources: Canberra, Australia, 2007.

59. Kuehne, G.; Bjornlund, H. Non-profit-maximising values and attitudes influencing irrigators' management response to new policy instruments. In Incentives and Instruments for Sustainable Irrigation; Bjornlund, H., Ed.; WIT Press: Southampton, UK, 2010; pp. 75-89.

60. Wong, P. 2009; 'Small Block Irrigators Exit Grant Package Expanded'. Media Release: Senator the Hon Penny Wong, Minister for Water and Climate Change. Available online: https://parlinfo.aph.gov.au/parlInfo/download/media/pressrel/2GET6/uploa d_binary/2get60.pdf (accessed on 16 September 2021).

61. O’Donnell, M.; Colby, B.G. Dry-Year Water Supply Reliability Contracts: A Tool for Water Managers. 2009. Available online: https:/ / climas.arizona.edu/sites/default/files/pdfewsr-dyo-final-5-12-101.pdf (accessed on 16 September 2021).

62. Grafton, R.Q.; Wheeler, S. Economics of water recovery in the Murray-Darling Basin, Australia. Annu. Rev. Resour. Econ. 2018, 10, 3.1-3.24. [CrossRef]

63. IID. Imperial Irrigation District 2004-2005 Fallowing Program Solicitation Announcement; IID: Imperial, CA, USA, 2004.

64. MWDSC-PVID. Landowner Agreement for Fallowing in the Palo Verde Irrigation District ("Landowner Agreement"). 2004. Available online: https:/ / www.mwdh2o.com/media/18478/palo-verde-irrigation-dist-mwd-forbearanceandfallowingprogr amagreement.pdf (accessed on 16 September 2021).

65. MWDSC-PVID. Fallowing Easement Deed. PVID-IID Landowner Agreement. Exhibit C. 2004. Available online: https://www. mwdh2o.com/media/18478/palo-verde-irrigation-dist-mwd-forbearanceandfallowingprogramagreement.pdf (accessed on 16 September 2021).

66. Jones, L.; Colby, B. Farmer participation in temporary irrigation forbearance: Portfolio risk management. Rural. Connect. 2010, 43-48.

67. MWDSC. Metropolitan Funded Palo Verde Irrigation District Forbearance and Fallowing Program Intentionally Created Surplus Certification Report. Calendar Year 2010. 2010. Available online: https:/ /www.mwdh2o.com/media/18478/palo-verde-irrigati on-dist-mwd-forbearanceandfallowingprogramagreement.pdf (accessed on 16 September 2021).

68. IID. Final Report 2/12/04, revised October 7, 2004. IID 2003 13-Month Emergency Fallowing Program Participants. December 1, 2003-December 31, 2004; IID: Imperial, CA, USA, 2004.

69. Kullman. Draft: Regional Assessment of Fallowing Programs. Lower Rio Grande Basin. Prepared for: New Mexico Interstate Stream Commission; Kullman Water Engineering, LLC: Santa Fe, NM, USA, 2020.

70. MWDSC-PVID. Short Term Emergency Fallowing Program 2009-2010; 2009; 14p. 2009, p. 14. Available online: https://www. mwdh2o.com/media/18478/palo-verde-irrigation-dist-mwd-forbearanceandfallowingprogramagreement.pdf (accessed on 16 September 2021).

71. IID. Imperial Irrigation District Fallowing Program Payments; IID: Imperial, CA, USA, 2017.

72. Downey Brand Attorneys LLP. Memorandum: PVID Federal Income Tax Issues on Water Transfers. Draft. 2004. Available online: https: / www.mwdh2o.com/media/18478/palo-verde-irrigation-dist-mwd-forbearanceandfallowingprogramagreem ent.pdf (accessed on 16 September 2021).

73. Smith, E. “SLIDES: PVID/MWD Land Management, Crop Rotation and Water Supply Program". Evolving Regional Frameworks for Ag-to-Urban Water Transfers. 11 December 2008. Available online: https:/ / scholar.law.colorado.edu/evolving-regional-fra meworks-for-ag-to-urban-water-transfers / 4 (accessed on 16 September 2021).

74. IID. Notice of Funding Availability Local Entity Mitigation Competitive Grant Program. IID Local Entity Mitigation: 2010 Competitive Grant Program Request for Proposals; IID: Imperial, CA, USA, 2010.

75. IID. Imperial Irrigation District Local Entity Mitigation Payments; IID: Imperial, CA, USA, 2020. 
76. IID. 2021 Local Entity Closing Disbursement Program: Request for Consideration for Grant Award, Overview and Interest Form; IID: Imperial, CA, USA, 2021.

77. Pearce, D.W.; Turner, R.K. Economics of Natural Resources and the Environment; JHU Press: Baltimore, MA, USA, 1990.

78. Perman, R.; Ma, Y.; Common, M.; Maddison, D.; McGilvray, J. Natural Resource and Environmental Economics, 4th ed.; Pearson Education: London, UK, 2011.

79. Bark, R.; Kirby, M.; Connor, J.; Crossman, N.D. Water allocation reform to meet environmental uses while sustaining irrigation: A case study of the Murray-Darling Basin, Australia. Water Policy 2014, 16, 739-754. [CrossRef]

80. Kiem, A.S. Drought and water policy in Australia: Challenges for the future illustrated by the issues associated with water trading and climate change adaptation in the Murray-Darling Basin. Global Environ. Chang. 2013, 23, 1615-1626. [CrossRef]

81. Haensch, J.; Wheeler, S.A.; Zuo, A. Do neighbors influence irrigators' permanent water selling decisions in Australia? J. Hydrol. 2019, 572, 732-744. [CrossRef]

82. Bateman, I.J.; Balmford, B. Public funding for public goods: A post-Brexit perspective on principles for agricultural policy. Land Use Policy 2018, 79, 293-300. [CrossRef]

83. ADA. An Introduction to Internal Drainage Boards. 2017. Available online: https://www.ada.org.uk/wp-content/uploads/2017 /12/IDBs_An_Introduction_A5_2017_web.pdf (accessed on 16 September 2021).

84. Campos, I.; Ng, K.; Penha-Lopes, G.; Pedersen, A.B.; Capriolo, A.; Olazabal, M.; Meyer, V.; Gebhardt, O.; Weiland, S.; Nielsen, H.Ø.; et al. Chapter 3-The Diversity of Adaptation in a Multilevel Governance Setting. In Adapting to Climate Change in Europe, Sanderson; Sanderson, H., Ed.; Elsevier: Amsterdam, The Netherlands, 2018; pp. 49-172. ISBN 9780128498873.

85. Hardiman, S.C.; Dunstone, N.J.; Scaife, A.A.; Smith, D.M.; Ineson, S.; Lime, J.; Fereday, D. The impact of strong El Niño and La Niña events on the North Atlantic. Geophys. Res. Lett. 2019, 46, 2874-2883. [CrossRef]

86. Morris, J.; Brewin, P. The impact of seasonal flooding on agriculture: The spring 2012 floods in Somerset, England. J. Flood Risk Manag. 2014, 7, 128-140. [CrossRef]

87. Arellano-Gonzalez, J.; Moore, F.C. Intertemporal arbitrage of water and long-term agricultural investments: Drought, groundwater banking, and perennial cropping decisions in California. Am. J. Agric. Econ. 2020, 102, 1368-1382. [CrossRef]

88. Zhang, X. Conjunctive surface water and groundwater management under climate change. Front. Environ. Sci. 2015, 3, 59. [CrossRef]

89. Casalini, F.; Bagherzadeh, M.; Gray, E. Building the Resilience of New Zealand's Agricultural Sector to Floods; OECD Food, Agriculture and Fisheries Paper; No 160. May 2021; OECD: Paris, France, 2021.

90. Gray, E.; Baldwin, K. Building the Resilience of United State's Agricultural Sector to Extreme Floods; OECD Food, Agriculture and Fisheries Paper; No 161; OECD: Paris, France, May 2021.

91. Cologna, V.; Bark, R.H.; Paavola, J. Flood risk perceptions and the UK media: Moving beyond "once in a lifetime" to "Be Prepared" reporting. Clim. Risk Manag. 2017, 17, 1-10. [CrossRef]

92. Navrud, S.; Vondolia, G.K. Farmers' preferences for reductions in flood risk under monetary and non-monetary payment modes. Water Resour. Econ. 2020, 30, 100151. [CrossRef]

93. Stone, J.; Costanigro, M.; Goemans, C. Public opinion on Colorado water rights transfers: Are policy preference consistent with concerns over impacts? J. Agric. Resour. Econ. 2018, 43, 403-422.

94. IPCC. Climate Change 2021, The Physical Science Basis. Contribution of Working Group I to the Sixth Assessment Report of the Intergovernmental Panel on Climate Change; Masson-Delmotte, V., Zhai, P., Pirani, A., Connors, S.L., Péan, C., Berger, S., Caud, N., Chen, Y., Goldfarb, L., Gomis, M.I., et al., Eds.; Cambridge University Press: Cambridge, UK, 2021. 